Agro-Science Journal of Tropical Agriculture, Food, Environment and Extension Volume 12 Number 1 January 2013 pp 32 - 36

ISSN IIIY-7455

\title{
INFLUENCE OF PIG MANURE, UREA AND COMBINATIONS OF THEIR REDUCED LEVELS ON THE PERFORMANCE OF AMARANTHUS CRUENTUS IN A RAINOFOREST ULTISOL
}

\author{
Otobong $^{1}$ B. Iren ${ }^{*}$ and Asawalam ${ }^{2}$ D. O. \\ ${ }^{1}$ Department of Soil Science Faculty of Agriculture, Forestry and Wildlife Resource \\ Management University of Calabar, Calabar Cross River State, Nigeria \\ *e-mail: myirenlady@gmail.com Department of Soil Science and Agroclimatology, \\ Michael Okpara University of Agriculture, Umudike, Abia State, Nigeria.
}

\begin{abstract}
The influence of sole and combined application of pig manure and urea on the performance of Amaranthus cruentus at Umudike in a rainforest Ultisol was investigated for two years. The study was laid out in a randomized complete block design with four replications. There were six treatments consisting of pig manure applied at $90 \mathrm{~kg} \mathrm{~N} / \mathrm{ha}$ (full dose of manure), urea applied at $60 \mathrm{~kg} \mathrm{~N} / \mathrm{ha}$ (full dose of urea), $1 / 2$ dose of manure $(45 \mathrm{~kg} \mathrm{~N} / \mathrm{ha})+1 / 2$ dose of urea $(30 \mathrm{~kg} \mathrm{~N} / \mathrm{ha}), 1 / 4$ dose of manure $(22.5 \mathrm{~kg} \mathrm{~N} / \mathrm{ha})+3 / 4$ dose of dose of dose of urea $(45 \mathrm{~kg} \mathrm{~N} / \mathrm{ha}), 3 / 4$ dose of manure $(67.5 \mathrm{~kg} \mathrm{~N} / \mathrm{ha})+$ $1 / 4$ dose of urea $(15 \mathrm{~kg} \mathrm{~N} / \mathrm{ha})$, and control (no manure, no urea). Amaranthus height was not significantly affected by the treatments when compared with the control, though the tallest plant height of $76.30 \mathrm{~cm}$ was obtained from the combination of $1 / 2$ manure $+1 / 2$ urea treatments. The overall results showed that the combination, $1 / 2$ manure $+1 / 2$ urea (i.e. $45 \mathrm{~kg} \mathrm{~N} / \mathrm{ha}$ of pig manure +30 $\mathrm{kg} N /$ ha of urea) gave significant $(P<0.05)$ increases in stem girth (17.42), number of leaves per plant (44.76), fresh yield (41.51 t/ha) and in the dry matter yield (3.49 t/ha) of Amaranthus than sole application of either of them, and is therefore recommended as the best for optimum production of Amaranthus in the study area.
\end{abstract}

Keywords: Amaranthus, pig manure, urea, Ultisol.

\section{INTRODUCTION}

The maintenance of soil fertility is essential in achieving and sustaining high crop yields over a period of time. Use of inorganic fertilizers has proven to be more convenient and impactful than the use of organic fertilizers, but the resulting soil physical degradation, increased soil acidity and soil nutrient imbalance have drawn the attention of researchers back to the use of organic manure. Application of organic materials as fertilizers provides growthregulating substances and improves the physical, chemical and microbial properties of the soil (Belay et al., 2001). Sole use of organic fertilizers to sustain cropping has, however, been reported to be inadequate, as they are required in rather large quantities to meet crops' nutrient requirements because of their relatively low nutrient content (Palm et al., 1997).

It has been reported by several researchers (Satyanarayana et al., 2002; Adeniyan and Ojeniyi, 2005; Obasi et al., 2006) that high and sustainable crop yields are only possible with integrated use of inorganic fertilizers with organic manure. Complementary application of inorganic and organic fertilizers increases nutrient availability and reduces losses by converting inorganic nitrogen into organic forms (Chand et al., 2006; Chen, 2008). It enhances the efficiency of the fertilizers and also reduces environmental problems that may arise from their use (Zublena et al., 1996; Hoffman et al., 2001).

This research was therefore, conducted to determine the combined effects of inorganic and organic fertilizers on the performance of Amaranthus and also to know the best combination of inorganic and organic fertilizers for Amaranthus production in a rainforest ultisol.

\section{MATERIALS AND METHODS}

The experiments were conducted at the Research Farm of Michael Okpara University of Agriculture, Umudike to determine the combined effects of organic and inorganic fertilizers on the performance of Amaranthus and also to establish the best combination of 
organic and inorganic fertilizers for Amaranthus production for two consecutive years.

There were six treatments with four replications, giving a total of 24 plots. The treatments were pig manure applied at $90 \mathrm{~kg}$ $\mathrm{N} / \mathrm{ha}$ (full dose of manure), urea applied at $60 \mathrm{~kg}$ $\mathrm{N} / \mathrm{ha}$ (full dose of urea), $1 / 2$ manure ( $45 \mathrm{~kg} \mathrm{~N} / \mathrm{ha}$ ) $+1 / 2$ urea $(30 \mathrm{~kg} \mathrm{~N} / \mathrm{ha}), 1 / 4$ manure $(22.5 \mathrm{~kg} \mathrm{~N} / \mathrm{ha})$ $+3 / 4$ urea (45 kg N/ha), $3 / 4$ manure $(67.5 \mathrm{~kg} \mathrm{~N} / \mathrm{ha})$ $+1 / 4$ urea (15 kg N/ha), and control (no manure, no urea).

The experimental design used was a randomized complete block design. The experimental area in each cropping season was slashed manually, ploughed and harrowed mechanically while the field was manually marked out with pegs. Flat beds were also manually made using a spade. Each plot measured $3 \mathrm{~m} \times 1.5 \mathrm{~m}\left(4.5 \mathrm{~m}^{2}\right)$. An alley of 1.2 $\mathrm{m}$ was left between blocks and $0.6 \mathrm{~m}$ between plots.

The various rates of pig manure were applied one week before planting (1 WBP) by broadcast with incorporation method, while urea fertilizer treatments were applied two weeks after planting (2 WAP) by band placement method. Amaranthus seeds were mixed with dried river sand first before sowing so as to ensure that the seeds were not planted too close together for proper management of the seed rate desired. The mixture was about $70 \%$ sand and $30 \%$ Amaranthus seeds. These were evenly distributed directly on drills at a distance of 10 $\mathrm{cm}$ between each row. The seedlings were later thinned down to one plant per stand few days after emergence at a spacing of $10 \mathrm{~cm}$ between plants. Therefore, the planting distance was 10 $\mathrm{cm} \times 10 \mathrm{~cm}$ giving a plant population of 450 plants per bed $\left(450 / 4.5 \mathrm{~m}^{2}\right)$ and $1,000,000$ plants per hectare. The plots were kept weed free throughout the crop growing period by hand pulling because of the closeness of the plants. Plots were irrigated manually using watering cans before planting and immediately after planting to ensure and enhance sprouting. Watering was done 2 times a day (morning and evening) at the initial stage of development, and was reduced to once (evening only) every day at the later stage. During this time there was a good canopy development that shaded the ground and reduced soil moisture loss.
Agronomic parameters measured included plant height $(\mathrm{cm})$, number of leaves per plant, stem girth, fresh yield and dry matter yield $(\mathrm{kg} / \mathrm{ha})$. Plant height was measured with a meter rule as the height from the base of the crop (ground level) to the tip of ten tagged plants, while the number of leaves was taken by counting the fully opened leaves per plant. These measurements commenced 3 WAP and continued at weekly interval until the end of the experiment. Harvesting was done at 5 WAP by uprooting the entire plant from an area of 100 $\mathrm{cm} \times 100 \mathrm{~cm}$ per plot and the fresh yield determined after rinsing the roots free of sand. For dry matter determination, the ten tagged plants were uprooted, rinsed, and oven-dried at $65^{\circ} \mathrm{C}$ to constant weight (Maerere et al., 2001) and the weight determined. Stem girth was measured at harvest using a venier calliper.

The data collected were subjected to analysis of variance (ANOVA) using the general linear models (GLM) procedures of the Statistical Analysis Systems programme (SAS, 1989) to determine treatment effects. Means were separated using the Fisher's Least Significant Difference (FLSD) at $5 \%$ level of probability.

\section{RESULTS AND DISCUSSION}

\section{Chemical composition of pig manure}

The analyses of the pig manure used for the study gave $2.87 \% \mathrm{~N}, 0.21 \% \mathrm{P}, 1.80 \% \mathrm{~K}, 30.29$ $\%$ O.C., $52.22 \%$ O. M., 10.55 C: $\mathrm{N}$ ratio, $4.0 \%$ $\mathrm{Ca}$ and $1.8 \% \mathrm{Mg}$.

\section{Growth parameters}

Plant height of Amaranthus was not significantly affected by the sole and combined use of pig manure and urea in the first and second cropping seasons as indicated in Table 1, although the tallest plant of $76.30 \mathrm{~cm}$ (5 WAP) was obtained from the $1 / 2$ manure $+1 / 2$ urea treatment . 
Table 1: Effects of sole and combined use of pig manure and urea on plant height in the $1^{\text {st }}$ and $2^{\text {nd }}$ cropping seasons

\begin{tabular}{|c|c|c|c|c|c|c|c|c|c|}
\hline \multirow{3}{*}{ Treatment } & \multicolumn{6}{|c|}{ Plant height $(\mathrm{cm})$} & \multirow{2}{*}{\multicolumn{3}{|c|}{ 5WAP }} \\
\hline & \multicolumn{2}{|c|}{$3 \mathrm{WAP}$} & \multicolumn{3}{|c|}{ 4WAP } & \multirow[b]{2}{*}{ Mean } & & & \\
\hline & $1^{\text {st }}$ & $2^{\text {nd }}$ & Mean & $1^{\text {st }}$ & $2^{\text {nd }}$ & & $1^{\mathrm{st}}$ & $2^{\text {nd }}$ & Mean \\
\hline Control & 12.25 & 12.30 & 12.28 & 24.35 & 23.45 & 23.90 & 56.60 & 55.75 & 56.18 \\
\hline Manure & 15.85 & 14.20 & 15.03 & 32.45 & 29.45 & 30.95 & 70.80 & 63.65 & 67.23 \\
\hline Urea & 18.10 & 16.60 & 17.35 & 37.65 & 36.20 & 18.46 & 78.35 & 72.80 & 75.58 \\
\hline $1 / 2 m+1 / 2 u$ & 16.95 & 17.00 & 16.98 & 39.28 & 39.30 & 39.29 & 76.23 & 76.36 & 76.30 \\
\hline $3 / 4 m+1 / 4 u$ & 17.75 & 16.40 & 17.08 & 35.65 & 32.50 & 34.08 & 73.40 & 68.90 & 71.15 \\
\hline $1 / 4 m+3 / 4 u$ & 19.00 & 15.90 & 17.45 & 38.45 & 35.10 & 36.78 & 77.45 & 70.25 & 73.85 \\
\hline $\operatorname{LSD}(0.05)$ & NS & NS & NS & NS & NS & NS & NS & NS & NS \\
\hline
\end{tabular}

Table 2: Effects of sole and combined use of pig manure and urea on number of leaves per plant in the $1^{\text {st }}$ and $2^{\text {nd }}$ cropping seasons

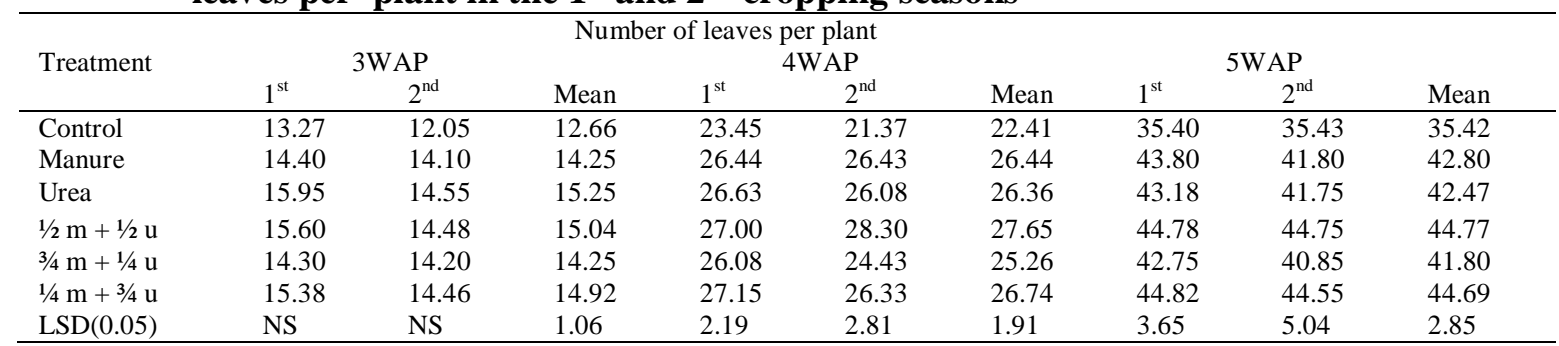

There was no significant difference in the number of leaves per plant at 3 WAP from either the sole or combined use of the treatments in the first and second cropping seasons as presented in Table 2, but the treatments significantly increased the number of leaves per plant relative to the control at 4 and 5 WAP. The highest number of leaves per plant was obtained from the $1 / 2$ manure $+1 / 2$ urea treatment combinations. The highest stem girth value of 17.42 was also obtained from the $1 / 2$ manure $+1 / 2$ urea treatment (Table 3). Generally, the best result was obtained from combined use of organic and inorganic fertilizers. This supports the findings of Akande et al. (1998) and Adediran et al. (2005) indicating a better effect of organic materials on Amaranthus when applied in combination with inorganic fertilizer.

\section{Fresh and dry matter yields of Amaranthus}

The highest fresh yield of Amaranthus of 42.80 t/ha obtained by the $1 / 4$ manure $+3 / 4$ urea treatment in the first cropping season was significant when compared with the sole manure treatment and the control, while the highest yield of $41.01 \mathrm{t} / \mathrm{ha}$ obtained from the $1 / 2$ manure $+1 / 2$ urea treatment in the second cropping season was significant relative to the control (Table 4). The mean data for the two years indicated that the $1 / 2$ manure $+1 / 2$ urea treatment recorded the highest fresh yield of $41.51 \mathrm{t} / \mathrm{ha}$, followed by the $1 / 4$ manure $+3 / 4$ urea which recorded 41.40 t/ha while the least yield of $22.75 \mathrm{t} / \mathrm{ha}$ was obtained from the control. The highest dry matter yield (3.49 t/ha) was also obtained from the $1 / 2$ manure $+1 / 2$ urea combination.

Generally the fresh yields obtained from all the treatments except the control in both the first and second cropping seasons were higher than the $25 \mathrm{t} / \mathrm{ha}$ reported by Tandon (1991) and Messiaen (1992) and that of $30 \mathrm{t} / \mathrm{ha}$ reported by Schippers (2000). This showed that Amaranthus responded positively to the soil amendments used.

It is evident from the present study that balanced fertilization using both organic and inorganic fertilizers enhanced optimum growth and yield of Amaranthus than sole application of either of them. This view has also been reported by several researchers (Palm et al., 1997; Adeniyan and Ojeniyi, 2005 Chen 2008). The combination of $45 \mathrm{~kg}$ N/ha of pig manure $(1 / 2$ manure) and $30 \mathrm{~kg} \mathrm{~N} / \mathrm{ha}$ of urea ( $1 / 2$ urea), though not significantly different from the combination of $22.5 \mathrm{~kg} \mathrm{~N} / \mathrm{ha}$ of pig manure $(1 / 4$ manure) and $45 \mathrm{~kg} \mathrm{~N} / \mathrm{ha}$ of urea ( $3 / 4$ urea), gave significant improvement in the performance of Amaranthus and is therefore recommended as the best for optimum production of Amaranthus in regions with similar environmental and climatic conditions as the study site. 
Table 3: Effects of sole and combined use of pig manure and urea on Amaranthus stem girth in the $1^{\text {st }}$ and $2^{\text {nd }}$ cropping seasons

\begin{tabular}{llll}
\hline & \multicolumn{2}{c}{ Stem girth } & Mean \\
\hline Treatment & $1^{\text {st }}$ cropping & $2^{\text {nd }}$ cropping & 9.77 \\
Manure & 9.98 & 9.58 & 13.96 \\
Urea & 14.20 & 17.03 & 15.47 \\
$1 / 2 \mathrm{~m}+1 / 2 \mathrm{u}$ & 16.60 & 13.83 & 17.42 \\
$3 / 4 \mathrm{~m}+1 / 4 \mathrm{u}$ & 17.83 & 13.73 & 14.54 \\
$1 / 4 \mathrm{~m}+3 / 4 \mathrm{u}$ & 15.25 & 14.90 & 15.71 \\
$\mathrm{LSD}(0.05)$ & 16.53 & 14.35 & 1.86 \\
\hline
\end{tabular}

Table 4: Effects of sole and combined use of pig manure and urea on Amaranthus fresh and dry matter yield in the $1^{\text {st }}$ and $2^{\text {nd }}$ cropping seasons

\begin{tabular}{lllllll}
\hline Treatment & $\begin{array}{l}\text { Fresh yield (t/ha) } \\
\text { st }\end{array}$ & \multicolumn{3}{c}{ Dry matter yield (t/ha) } \\
& $2^{\text {nd }}$ cropping & Mean & \multicolumn{2}{c}{$1^{\text {st }}$ cropping } & $2^{\text {nd }}$ cropping & Mean \\
\hline Control & 23.50 & 22.00 & 22.75 & 2.20 & 2.11 & 2.16 \\
Manure & 31.80 & 32.11 & 31.96 & 3.31 & 3.20 & 3.26 \\
Urea & 41.13 & 39.97 & 40.55 & 3.02 & 3.01 & 3.02 \\
$1 / 2 \mathrm{~m}+1 / 2 \mathrm{u}$ & 42.00 & 41.01 & 41.51 & 3.68 & 3.29 & 3.49 \\
$3 / 4 \mathrm{~m}+1 / 4 \mathrm{u}$ & 37.00 & 32.51 & 34.76 & 3.22 & 3.13 & 3.18 \\
$1 / 4 \mathrm{~m}+3 / 4 \mathrm{u}$ & 42.80 & 40.00 & 41.40 & 3.56 & 3.19 & 3.38 \\
LSD $(0.05)$ & 9.96 & 9.87 & 9.25 & 0.91 & 0.91 & $\mathrm{NS}$ \\
\hline
\end{tabular}

\section{REFERENCES}

Adediran, J. A., M. O. Akande and W. B. Akanbi (2005). Effect of organic root plus (Biostimulant) on nutrient content, growth and yield of tomato. Nigerian Journal of Soil Science, 15: 26-33.

Adeniyan, O. N. and S. O. Ojeniyi (2005). Effect of poultry manure, NPK 15-1515 and combination of their reduced levels on maize growth and soil chemical properties. Nigerian Journal of Soil Science, 15:34-41.

Akande, M. O., J. A. Adediran and O. A. Ashaye (1998). Evaluation of organic root plus (Biostimulant) on the growth and yield of Amaranthus. Bioscience Research Communication, vol. 2.(1): 15-19.

Belay, A., A. S. Classens, F. C. Wehner and J. D. Beer (2001). Influence of residual manure on selected nutrient elements and microbial composition of soil under long-term crop rotation. S. Afric. J. Plt. Soil, 18:1-6.

Chand, S., M. Anwar and D. D. Patra (2006). Influence of long-term application of organic and inorganic fertilizers to build up soil fertility and nutrient uptake in mint-mustard cropping sequence. Communications in Soil Science and Plant Analysis, 37:63-76.

Chen, Jen-hshuan (2008). The combined use of chemical and organic fertilizers and/or Biofertilizer for growth and soil fertility. Food and Fertilizer Technology Center (FFTC) Database, Taiwan.

Hoffman,Irene; D. Gerling; U. S. Kyiogwom and A. Mane-Bielfeldt (2001). Farmer's management strategies to maintain soil fertility in a remote area in northwest Nigeria. Elsevier. Agriculture, Ecosystem and Environment 6:263275.

Maerere, A. P.; G. G. Kimbi and D. L. M. Nonga (2001). Comperative effectiveness of animal manures on soil chemical properties, yield and root growth of Amaranthus (Ameranthus Cruentus L.). AJST, Vol. 1, 4: 14 -21

Messiaen, C. M. (1992). The tropical vegetable garden: Principles for improvements and increased production with application to the main vegetable types, 514 pages.

Obasi, M. N., E. N. A. Mbanaso, A. O. Ano and O. Onwubiko (2006). Effect of combinations of organic materials and mineral fertilizer on growth and yield of cocoyam. Proceedings of the $40^{\text {th }}$ conference of the Agricultural Society of Nigeria

(ASN), Umudike, pp386-388. Palm, C. A., R. J. K. Myers and S. M. Nandwa (1997). Combined use of organic and inorganic nutrient sources for soil fertility maintenance and replenishment. In:Replenishing soil fertility in Africa. R. J. Buresh, P. A. Sanchez and F. Calhoun (Eds). Special publication, 
51:193-217, Madison. WI. Soil Science Society of America.

SAS, Institute (1989). Statistical Analysis System. User's guide: Statistics SAS Institute, Cary, N. C.

Satyanarayana, V. M., P. V. Vera Prasad, V. R. K. Murphy and K. J. Boots (2002). Influence of integrated use of farmyard manure and inorganic fertilizer on yield and yield components of irrigated lowland rice. J. Plt. Nutr. 25 (10):20812090.

Schippers, R. R. (2000). African indigenous vegetables. An overview of the cultivated species. Chatham, UK: Natural Resources Institute / ACP - EU Technical
Centre for Agricultural and Rural Cooperation, 214pages. Tandon, H. L. S (1991). Fertilizer recommendations for Holticultural Crops- A

Guidebook. $2^{\text {nd }}$ ed. Fertilizer Development and consultation organization, New Delhi India, 104pages.

Zublena, J. P.; J. C. Barker and T. A. Carter (1996). Poultry manure as a fertilizer source. In: Water quality and waste management. North Carolina Cooperative Extension Service. AG 439-445. 